Diabetologia 9, 174-177(1973)

(C) by Springer-Verlag 1973

\title{
ORIGINALS
}

\section{Physiological Factors Influencing Insulin Clearance by the Isolated Perfused Rat Liver}

\author{
A.M. MoCarroll and K.D. Buchanan \\ Department of Medicine, Queen's University, Belfast; Ireland \\ Received: August 24, 1972, accepted: December 20, 1972
}

\begin{abstract}
Summary. Hepatic insulin clearance was studied in normal male and female Wistar rats using the isolated liver perfusion technique and the dextran coated charcoal radioimmunoassay for insulin. The following results were obtained: - 1 . In male rats there was a progressive increase in clearance with increasing body weight, liver weight and age. -2 . In adult female rats clearance was
\end{abstract}

significantly greater than in comparable males, but no relationship between liver weight and clearance was observed. -3 . With each increase in insulin concentration there was an apparent decrease in clearance.

Key words: Insulin, clearance, perfusion, radioimmuno. assay.

\section{Introduction}

The mammalian liver has been shown to be one of the major organs involved in insulin degradation Mirsky [14], Williams et al., [23] and Freinkel [6]. All endogenous insulin must pass through it en route to muscles and other target organs. Disturbances of hepatic insulin metabolism have been variously suggested to explain the carbohydrate intolerance of diabetes mellitus though the evidence is inconclusive and to some extent conflicting Mirsky [13], Tomizawa and Varandani [22] and Cerasi and Luft [3]. There is, however, little information on the effects of such physiological variables as age, weight, sex and substrate concentration on insulin clearance by the normal liver. The present study was undertaken to evaluate these factors, and to standardise conditions under which hepatic insulin degradation might be studied both in the normal animal and in states of carbohydrate intolerance.

\section{Materials and Methods}

The isolated intact rat liver perfusion technique of Miller et al. [12] and Schimassek [20] as modified by Hems et al. [8] was employed throughout these studies. Each insulin clearance experiment was preceded by a control perfusion period of $15 \mathrm{~min}$. Pork insulin (Novo 10 times recrystallised Lot No. $\$ 23267$ ) of potency 25 I. U./mg was then added to the perfusion medium to give a final concentration of $200 \mu \mathrm{U} / \mathrm{ml}$ unless otherwise stated in the protocol. A further 6 min perfusion period was allowed for equilibration Solomon et al. [21] after which the first of a series of approximately $0.5 \mathrm{ml}$ samples was taken directly from the hepatic effluent. Further samples were taken $3,6,9,14,19,24$ and $34 \mathrm{~min}$ later. Samples were immediately centrifuged to remove red blood cells and stored frozen at $-20^{\circ} \mathrm{C}$. Insulin in the samples was subsequently measured by the radioimmunoassay technique of Yalow and Berson [24] as modified by Herbert et al. [9] and Buchanan and McCarroll [1].

\section{Calculation of results}

The results were calculated as the percentage of maximal (initial) concentration determined $6 \mathrm{~min}$ after the insulin had been added to the perfusate and the half life determined from the linear regression equation of insulin concentration against time. No correction was made for the error introduced by the decreasing perfusate volume as this was less than $5 \%$.

\section{Experimental Protocol 1}

The effect of age, weight and sex on hepatic insulin half life $(t 1 / 2)$. Eighty-four Wistar albino rats fed ad libitum and with free access to water were divided into 4 groups according to weight and age. There was no sig. nificance difference in weight between the sexes within groups. The isolated intact livers were perfused with $200 \mu \mathrm{U}$ of pork insulin per ml of perfusate.

\section{Experimental Protocol 2}

The effect of the amount of substrate present on hepatic insulin $t 1 / 2$. Thirty-one male Wistar rats 150 $200 \mathrm{~g}$ were fed ad libitum with free access to water and divided into 4 groups. Liver perfusion studies were carried out with $50,200,500$ and $1,000 \mu \mathrm{U}$ of insulin per $\mathrm{ml}$ of perfusate. These concentrations were chosen to mimic what might be expected to be found in the portal vein

(1) under fasting conditions

(2) post prandial - low physiological response

(3) post prandial - high physiological response

(4) at the approximate upper limit of the biological range.

\section{Results}

The effect of age, weight and sex on hepatic insulin $t \frac{1}{2}$

Table 1 shows the hepatic insulin $t \frac{1}{2}$ in different weight-age-groups. It will be seen that there is a progressive decrease in $t \frac{1}{2}$ with increasing weight and age except in females of Group 4.

Analysis of variance between male groups, Table 2, shows a highly significant difference, $p<0.001$. It is clear that both age and weight of male animals have a significant effect on insulin $\mathrm{t} \frac{1}{2}$ except between Groups 2 and 3. 
In females, Table 3 , analysis of variance also shows a significant difference between groups. In this case the difference lies between Group 1 and the other 3 groups.

The relationship between body weight and the weight of liver tissue in the two sexes is shown in
The effect of substrate concentration on hepatic insulin $t \frac{1}{2}$

The results are given in Table 5. Insulin t $\frac{1}{2}$ increases progressively with increasing substrate concentration. The difference is highly significant between all groups except 2 and 3.

Table 1. Hepatic insulin half-life in different weight-age groups

\begin{tabular}{|c|c|c|c|c|}
\hline Group & Sex & $\begin{array}{l}\text { No. of } \\
\text { rats }\end{array}$ & Mean $t 1 / 2 \mathrm{~min}$ & $\begin{array}{l}\text { Significance of } \\
\text { difference } \\
\text { between sexes } \\
\text { within groups }\end{array}$ \\
\hline \multirow{2}{*}{ 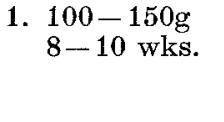 } & $\mathbf{M}$ & 7 & $22.9 \pm \mathbf{3 . 3}$ & \multirow[b]{2}{*}{$\begin{array}{l}t=0.9843 \\
0.2>P>0.15\end{array}$} \\
\hline & $\mathbf{F}$ & 6 & $\begin{array}{l}8.7 \\
19.22+1.19 \\
2.87\end{array}$ & \\
\hline \multirow[t]{2}{*}{$\begin{array}{l}\text { 2. } 150-200 \mathrm{~g} \\
10-12 \mathrm{wks} .\end{array}$} & $\mathbf{M}$ & 10 & $\underset{2.57}{18.1} \pm 0.81$ & \multirow{2}{*}{$\begin{array}{l}t=2.2609 \\
0.01>P>0.005\end{array}$} \\
\hline & $\mathbf{F}$ & 10 & $\begin{array}{l}15.7+0.7 \\
2.25\end{array}$ & \\
\hline \multirow{2}{*}{$\begin{array}{l}200-300 \mathrm{~g} \\
12-16 \text { wks. }\end{array}$} & $\mathbf{M}$ & 15 & $16.5 \pm 1.07$ & \multirow{2}{*}{$\begin{array}{l}t=2.0648 \\
0.025>P>0.0125\end{array}$} \\
\hline & $\mathrm{F}$ & 15 & $\begin{array}{l}13.71+0.8 \\
3.1\end{array}$ & \\
\hline \multirow[t]{2}{*}{$\begin{array}{l}\text { 4. } 300 \mathrm{~g}+ \\
16-20 \text { wks. }\end{array}$} & $\mathrm{M}$ & 15 & $\begin{array}{c}10.97 \\
3.07\end{array}$ & \multirow{2}{*}{$\begin{array}{l}t=1.6879 \\
0.1>P>0.05\end{array}$} \\
\hline & $\mathbf{F}$ & 6 & $\begin{array}{l}14.47 \pm 2.7 \\
6.68\end{array}$ & \\
\hline
\end{tabular}

Table 2. Analysis of variance of hepatic insulin half-life in males

\begin{tabular}{llll}
\hline Groups & $t$ & $p$ & \\
\hline 1 and 2 & 2.1428 & $0.025>P>0.0125$ & Correlation \\
1 and 3 & $\mathbf{3 . 0 7 6 9}$ & $0.0025>P>0.0005$ & coefficient \\
1 and 4 & 5.7692 & $P<0.0005$ & $r=0.6627$ \\
2 and 3 & 0.8649 & $0.2>P>0.15$ & $P<0.001$ \\
2 and 4 & 3.8919 & $P<0.0005$ & \\
3 and 4 & $\mathbf{3 . 3 7 3 5}$ & $P<0.0005$ & \\
\hline
\end{tabular}

Table 3. Analysis of variance of hepatic insulin half-life in females

\begin{tabular}{llll}
\hline Groups & $t$ & $p$ & \\
\hline 1 and 2 & 1.8789 & $0.05>P>0.025$ & Correlation \\
1 and 3 & 3.0955 & $0.0025>P>0.0005$ & coefficient \\
1 and 4 & 2.2405 & $0.0125>P>0.01$ & $r=0.4748$ \\
2 and 3 & 1.2933 & $0.10>P>0.05$ & $0.01>P$ \\
2 and 4 & 0.5684 & $0.30>P>0.25$ & $>0.001$ \\
3 and 4 & 0.4269 & $0.35>P>0.30$ & \\
\hline
\end{tabular}

Table 4. It will be seen that there is a direct relationship between body weight and the weight of the liver in both sexes. For any given body weight there is no difference in liver weight between the sexes, except in Group 1 in which the liver weight of females was significantly less than that of males.

The effect of sex on insulin $t_{2}^{1}$ is also shown in Table 1. No significant difference was noted between sexes in Group 1 or in Group 4. In Groups 2 and 3, however, there was a highly significant difference between the sexes, the $t \frac{1}{2}$ being much shorter in the females.

\section{Discussion}

Body weight, liver weight and age:

These three factors are considered together because a highly significant positive correlation $(p<0.001)$ was shown to exist between them in both male and female rats (Table 4). The finding of a progressive decrease in insulin $\mathrm{t} \frac{1}{2}$ in male rats with increasing body weight, liver weight and age is in keeping with that of Mirsky and Perisutti [16] and Diengott et al. [4]. However, in adult female rats no such relationship between liver weight and insulin $t \frac{1}{2}$ was observed. It would appear that for a given substrate concentration the rate of hepatic insulin clearance in male rats is directly related to the amount of available liver tissue, but that in comparable adult females other factors, perhaps hormonal, may also be operative.

\section{The effect of sex on hepatic insulin $t \frac{1}{2}$}

There are apparently no published data on the relationship between the sex of an animal and the rate of hepatic insulin clearance. The results of the experiments in this study indicate that the clearance of insulin by the livers of $150-300 \mathrm{~g}$ (approximately $10-16$ weeks old) female rats is significantly greater than in males of similar weight and age. Rats of this age are in the most active reproductive stage of their lives, so that maximal hormonal differences between the sexes are to be expected. That female hormones do influence insulin disposal in the liver is strongly suggested by the work of Goodner and Freinkel [7] which showed that insulin turnover in pregnant rats is ac- 
celerated to a degree only partly explained by the presence of the products of conception.

\section{The effect of substrate concentration on hepatic insulin $t \frac{1}{2}$}

The enzyme system responsible for insulin inactivation has been shown by numerous workers to obey first order kinetics Mirsky and Broh-Kahn [15], Mirsky et al. [17], Bürgi et al. [2] and Marshall et al. [11]. The rate of elimination of insulin by the enzyme system that high concentrations produce enzyme inhibition. Dixon and Webb [5] described several examples of this phenomenon and suggested that there might be competitive inhibition by the substrate itself. A second possible explanation is that in any preparation other than the purified enzyme itself, at least two other steps are interposed between the union of substrate and enzyme. These are the uptake or 'capture' of substrate by the liver cells, and transcellular passage

Table 4. Liver weights in 4 groups

\begin{tabular}{|c|c|c|c|c|c|c|}
\hline \multicolumn{2}{|c|}{ Group } & \multirow{2}{*}{$\begin{array}{l}\text { No. of } \\
\text { rats }\end{array}$} & \multirow{2}{*}{$\begin{array}{l}\text { Sex } \\
\text { M }\end{array}$} & $\begin{array}{l}\text { Mean liver wt. } \\
\text { (g) }\end{array}$ & \multicolumn{2}{|l|}{ Significance of } \\
\hline \multirow{2}{*}{\multicolumn{2}{|c|}{$\begin{array}{l}100-150 \mathrm{~g} \\
8-10 \text { weeks }\end{array}$}} & & & $5.28 \pm 0.24$ & & \multirow{8}{*}{$\begin{array}{l}\text { Correlation } \\
\text { coefficient } \\
\text { (males) } \\
r=0.9427 \\
P<0.001\end{array}$} \\
\hline & & 4 & F & $\begin{array}{l}4.47 \\
0.57\end{array}$ & $0.05>P>0.025$ & \\
\hline \multirow[t]{2}{*}{2.} & \multirow{2}{*}{$\begin{array}{l}150-200 \mathrm{~g} \\
10-12 \text { weeks }\end{array}$} & 5 & $\mathbf{M}$ & $\begin{array}{l}6.68 \pm 0.23 \\
0.51\end{array}$ & $t=0.3813$ & \\
\hline & & 5 & $\mathbf{F}$ & $\begin{array}{l}6.78 \pm 0.13 \\
0.29\end{array}$ & $0.40>P>0.35$ & \\
\hline \multirow[t]{2}{*}{3.} & \multirow[t]{2}{*}{$\begin{array}{l}200-300 \mathrm{~g} \\
12-16 \text { weeks }\end{array}$} & 5 & M & $\begin{array}{l}9.86 \pm 0.57 \\
1.29\end{array}$ & $6=1.8202$ & \\
\hline & & 5 & $\mathbf{F}$ & $\begin{array}{l}8.76 \pm 0.18 \\
0.40\end{array}$ & $0.10>P>0.05$ & \\
\hline \multirow[t]{2}{*}{4.} & \multirow[t]{2}{*}{$\begin{array}{l}300 \mathrm{~g}+ \\
16-20 \text { weeks }\end{array}$} & 4 & M & $\begin{array}{c}12.46 \\
1.17\end{array}$ & \multirow{2}{*}{$\begin{array}{l}t=0.4660 \\
0.35>P>0.30\end{array}$} & \\
\hline & & 4 & $\mathbf{F}$ & $\begin{array}{l}12.05 \pm 0.74 \\
1.48\end{array}$ & & \\
\hline
\end{tabular}

Table 5. Hepatic insulin half-life at 4 levels of substrate

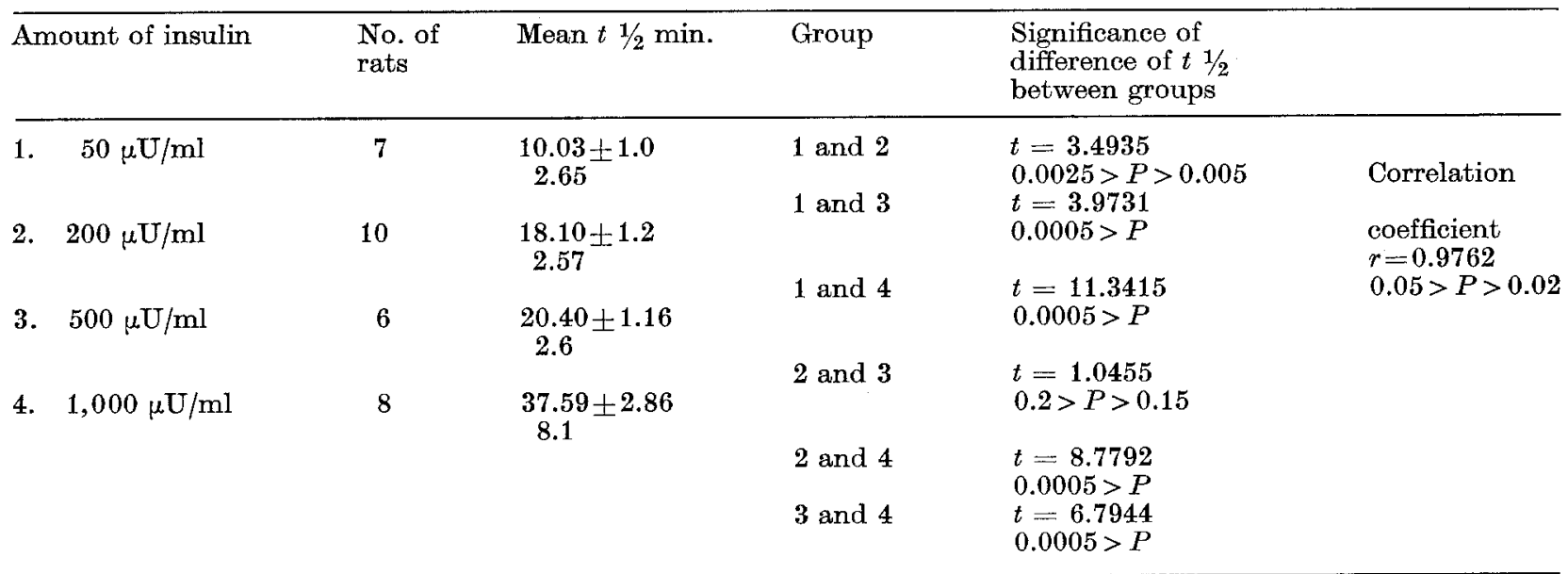

should therefore be proportional to the amount of substrate presented to it. Consequently insulin $t \frac{1}{2}$ should be constant at all substrate concentrations. However, the results presented here (Table 5) show that insulin $\mathrm{t} \frac{1}{2}$ increases progressively with each increase in substrate concentration.

There are at least two possible explanations for the discrepancy between these findings and those predicted by enzyme kinetic studies. The first is that at low substrate concentrations first order kinetics prevail, but of the hormone to reach the reaction site. The possible influence of such factors on the measured rate of insulin disposal was first suggested by Mirsky and Perisutti [16] who demonstrated that liver slices inactivated insulin more slowly than equivalent amounts of homogenised tissue. Further, the liver has been shown to remove $20-50 \%$ of insulin in the first single passage through it, indicating its vast capacity for hormone uptake Kaplan and Madison [10] and Samols and Ryder [19]. Mortimore and Tietze [18] have con- 
cluded from their investigations on the capture mechanisms of the liver that the ultimate rate limiting factor in hepatic clearance of insulin may be its transfer from the site of uptake to the degrading enzyme system. Finally, it is clear that insulin concentration should be taken into account in any experiment using the isolated perfused rat liver before valid comparisons can be made.

Acknowledgements. We wish to thank Novo Labora. tories, Copenhagen, for the supply of insulin used in this study.

A. M. McC. wishes to thank the Research Committee of the Royal Victoria Hospital, Belfast, for the Fellowship during which this work was carried out.

\section{References}

1. Buchanan, K.D., McCarroll, A.M.: Radioimmunoassay methods. 1st ed. Kirkham, K.E., Hunter, W.M., p. 136-142. Edinburgh: E. and S. Livingstone 1971.

2. Bürgi, H., Kopetz, K., Schwarz, K., Froesch, E.R.: Fate of rat insulin in rat liver perfusion studied by adipose tissue assay. Lancet 1963 II, $314-316$.

3. Cerasi, E., Luft, R.: Disappearance rate of exogenous insulin, insulin sensitivity, responses of plasma growth hormone and cortisol and urinary epinephrine to hypoglycaemia in prediabetic subjects. Horm. Metab. Res. 1, 221-223 (1969).

4. Diengott, D., Halevy, S., Guggenheim, K. : Effect of nutritional deficiencies on hepatic insulinase in rats. Endocrinology 65, 602-606 (1959).

5. Dixon, M., Webb, E.C.: Enzymes 2nd ed. p. 75-80. New York: Academic Press Inc. 1964.

6. Freinkel, N.: Insulin metabolism and pregnancy. Arch. intern. Med, 109, 235-244 (1962).

7. Goodner, C.J., Freinkel, N.: Carbohydrate metabolism in pregnancy. The turnover of $I 131$ insulin in the pregnant rat. Endocrinology 67, 862-872 (1960).

8. Hems, R., Róss, B.D., Berry, M.N., Krebs, H.A.: Gluconeogenesis in the perfused rat liver. Biochem. J. 101, 284-292 (1966).

9. Herbert, V., Lau, K., Gottlieb, C.W., Bleicher, S.J.: Coated charcoal immunoassay of insulin. J. clin. Endocr. 25, 1375-1384 (1965).

10. Kaplan, N., Madison, L.L.: Effects of endogenous insulin secretion on the magnitude of hepatic binding of labelled insulin during a single transhepatic circulation in human subjects. Clin. Res. 7, 248 (1959).
11. Marshall, A., Gingerich, R.L., Wright, P.H.: Hepatic metabolism of insulin in vitro. Clin. Res. $1833(1970)$.

12. Miller, L.L., Bly, C.G., Watson, M.L., Bale, W.F.: The dominant role of the liver in plasma protein synthesis. J. exp. Med. 94, $431-453$ (1951).

13. Mirsky, I.A.: Some consideration of the etiology of diabetes mellitus in man. Proc. Amer. Diabetes Ass. 5, 119-138 (1945).

14. Mirsky, I.A.: Insulinase, Insulinase-inhibitors, and diabetes mellitus. Recent Progr. Hormone Res. 13, $429-471$ (1957).

15. Mirsky, I.A., Broh-Kahn, R.H.: The inactivation of insulin by tissue extracts. I. The distribution and properties of [insulin inactivation extracts (insulinase). Arch. Biochem. 20, 1-9 (1949).

16. Mirsky, I.A., Perisutti, G.: The inactivation of insulin by liver slices of the rat. Endocrinology $\mathbf{5 2}$, $698-704(1953)$.

17. Mirsky, I.A., Perisutti, G., Jinks, R.: The destruction of insulin by intact mice. Endocrinology 56, 484-488 (1955).

18. Mortimore, G. F., Tietze, F.: Studies on the mechanism of eapture and degradation of insulin-I. 131 by the cyclically perfused rat liver. Ann. N.Y. Acad. Sci. 82, 329-337 (1959).

19. Samols, E., Ryder, J.A.: Studies on tissue uptake of insulin in man using a differential immunoassay for endogenous and exogenous insulin. $J$. clin. Invest. 40, 2092-2102 (1961).

20. Sehimassek, H.: Metabolite des Kohlenhydratstoffwechsels der isoliert perfundierten Rattenleber. Biochem. Z. 336, $460-467(1963)$.

21. Solomon, S. S., Fenster, L. F., Ensinck, J. W., Williarns, R.H.: Clearance studies of insulin and non-supressible insulin-like activity (NSILA) in the rat liver. Proc. Soc. exp. Biol, 126, 166-169 (1967).

22. Tomizawa, H.H., Varandani, P.T.: Glutathione insulin transhydrogenase of human liver. J. biol. Chem. 240, 3191-3194 (1965).

23. Williams, R.H., Hay, J.S., Tjaden, M.B.: Degradation of insulin-I.131 and glueagon-I-131 and factors influencing it. Ann. N.Y. Acad. Sci. 74, 513-529 (1959).

24. Yalow, R.A., Berson, S.A.: Immunoassay of endogenous plasma insulin in man. $J$, clin. Invest. 39, $1157-1175(1960)$.

\section{A. M. MeCarroll, M.D.}

Dept. of Medicine

Institute of Clinical Science

Grosvenor Road

Belfast BT $126 \mathrm{BJ}$

Ireland 